\title{
CS Resararch Suare \\ Genetic analysis of Sperata sarwari (Singharee) population fragmentized by Physical barriers in the Indus drainage system of Punjab, Pakistan.
}

\section{Asma Aziz ( $\square$ asma.aziz843@gmail.com ) \\ Government College University , Department of Zoology, Allama Iqbal road, 38000 Faisalabad, Pakistan.}

\section{Farhat Jabeen}

Department of Zoology, Government College University Allama Iqbal Road, 38000, Faisalabad, Pakistan.

\section{Muhammad Nafees}

State Key Laboratory of Pollution Control and Resource Reuse, School of Environment, Nanjing University, Nanjing, Jiangsu, 210023, china

\section{Adiba Khan Sehrish}

State Key Laboratory of Pollution Control and Resource Reuse, School of Environment, Nanjing University, Nanjing, Jiangsu, 210023, China

Inayat Ullah

Government College University Allama Iqbal Road, 38000, Faisalabad, Pakistan.

\section{Zahid Sharif Mirza}

Fisheries Research and Training Institute Lahore, Department of Fisheries, Punjab Pakistan

\section{Muhammad Ahmad Raza}

Akhuwat Faisalabad Institute of Research Science and Technology, Faisalabad Pakistan

\section{Sami Ullah}

Akhuwat Faisalabad Institute of Research Science and Technology, Faisalabad Pakistan

Noor Afshan

Akhuwat Faisalabad Institute of Research Science and Technology, Faisalabad Pakistan

\section{Research Article}

Keywords: Physical barriers, RAPD markers, genetic variability

Posted Date: April 22nd, 2021

DOI: https://doi.org/10.21203/rs.3.rs-162441/v1

License: (c) (i) This work is licensed under a Creative Commons Attribution 4.0 International License. Read Full License 


\section{Abstract}

Physical barriers like head works, dams barrages are main cause of fragmentation and declining of freshwater fish population in natural habitat. Present study focused on RAPD marker technique to assess the genetic variability among and between the populations of endangered sperata sarwari (Singharee) inhabited in the Indus drainage system of Punjab. Total eight populations (80 speciemen) of $S$. sarwari were collected from the up and downstream of four Rivers (Chenab, Jhelum, Ravi and Indus) of Punjab. Genomic DNA isolated from muscle tissue of adipose side and ten RAPD marker were used, which produced 50 scorable bands with average band ranging from 250-1050 bp which used for further genetic analysis of $S$. sarwari. Downstream Indus population of $S$. sarwari showed highest values of observed alleles (na), effected alleles (ne), Nei's diversity (h), Shannon index (I) and polymorphism which indicated that downstream Indus population was more genetically variant. The genetic variability $(0.5124)$ and genetic flow $(0.4758)$ among the eight population $S$. sawari was observed. The up and downstream population showed the highest genetic distance (0.5738) and lowest genetic similarities (0.5634) which indicated complete isolation of Ravi population from other six population. Dendrogram showed that up and downstream Ravi population was completely isolated from the other six up and down stream population of $S$. sarwai. Overall results indicated that the presence of high fragmentation in River Ravi caused the destruction of habitat and decline in population of $S$. sarwai in the River Ravi.

\section{Introduction}

Rivers are complex systems which provides natural habitat to fish species. Fishes show different tolerance level to environmental stressor's that enables fish to survive in hostile condition of the environment (Cooke et al. 2013). Most of the species are considered to be endangered due to the declining of their natural habitat and also reduced in numbers and sizes of populations. The crucial factors responsible for the decline in the number and size of different fish population involve alternation of climate and habitat, pollution, dam construction, fragmentation, eutrophication, replacement of invasive or intentionally introduced species, over-fishing, the aquarium pet trade, river flow modification, and even the consideration of the most optimistic climate change scenario points to the likelihood of ex-situ management of many species for their survival (Jeong et al. 2012;Kelly et al. 2013; Reis 2013; Gupta and Homechudhuri 2015; Gallardo et al. 2016, Pauly and Zeller 2016; Medeiros et al., 2016; Gold et al., 2017; Santos et al., 2017; Filho et al. 2018; Martinz et al. 2018; Mahboob et al. 2019; LoperaBarrero et al. 2019).

Population genetics shows distribution of genetic variability that is affected by natural selection, mutation, migration, population size and genetic drift not only influenced the genetic variations (Hansen 2003; Xia et al. 2014, 2015; Liu et al. 2019) and diversity of the population but was critical to the conservation of species. The genetic variation can be detected by the morphological parameter which was frequently concealed by the environmental factors and infrequency of observable morphological parameters reduced the genetic variability (Hedrick 2005; Mix et al. 2006). The native extinction was high in small fragmentized populations due to loss of genetic diversity and interruption of genetic drift and inbreeding within and among populations (Maskur 2002; Ruzafa et al. 2006; Kahl et al. 2008; Syandri et al. 2013; Coleman et al. 2017). Liu et al. (2019) reported that habitat fragmentation is one of the main cause of reduction in biodiversity of aquatic organism like freshwater mussel and dams had adverse effect on aquatic habitat, population genetics and fish communities and other aquatic animals (Cheng et al, 2013; Cheng et al. 2018; Morita and Yamamoto 2002; Roberts et al. 2013; Terborgh et al., 2001; Wu et al. 2003)

Ferguson et al. (2019) reported the declining of S.trutta (sea trout) due to the presences of barriers such as hydroelectric dams which caused the reproductive and genetic isolation of S.trutta population. Due to the development of PCR technique (Ferguson et al. 1995), molecular markers such as SNPs (Single Nucleotide Polymorphism), RAPD (Random Amplified Polymorphic DNA) and SSR (Short Sequence repeat or microsatellite) used directly to identify genetic diversity and distribution of the population. (Duran et al. 2009; Pujolar et al. 2009). Genetic information used to determine population structure, size (Luikart et al. 2010; Waples and Do 2010; Ahmad et al. 2012; Mojekwu et al. 2012), stability or declining in population and the relative time of declining in population (Williamson-Natesan 2005). It provides the information about the

Page $2 / 21$ 
patterns of individual migration (DeHaan et al. 2011; Vollestad et al. 2012) and gene flow among populations. Genetic data can also be imported to report the biology and demographic status of a species (Smith et al. 2011; Homola et al. 2012).

RAPD and SSR markers widely used (Liu and Cordes 2004; Muneeret al. 2011) in several different stduies ( Ramanadevi and Tharngaraj 2014; Achrem et al. 2015) for different fish population or species RAPD maker used not only for molecular characterization, identification, genetic diversity, genetic verability Genetic technologies have successfully been applied in species identification, studying the phylogenetic structure, conservation, monitoring fisheries and enhancement operations (Muneeret al., 2011; Usman et al. 2013; Asagbra et al. 2014; Vasave et al. 2014; Marimuthu et al. 2015; Kabir et al. 2017; Amit and Preeti 2020; Miah et al. 2020). Furthermore, genetic data have provided useful insight in setting up conservation priorities for many imperiled species (Lal et al. 2006; Muneeret al. 2011; Carison et al. 2015). Genetic variability provides the vital information to evaluate the endangered fish stocks.

In a given environment, the genetic diversity among different populations, either endemic or recent invasion can be detected through phylogenetic reconstruction approach using RAPD and SSR markers. Numerous studies has provided literature regarding the molecular diversity of wild populations of many fish species in the regions (Barman et al. 2003; Islam and Alam 2004; Lal et al. 2006; Sivaraman et al. 2010).

The status of $S$. sarwari is nearly "endangered" due to the declining stock in natural waters due to overfishing, pollution and low migration between population through dams and barrages. Keeping in view of the importance of $S$. sarwari, there is an urgent need to conserve $S$. sarwari in natural water bodies of Pakistan. In Pakistan, limited information is available on the meristic and morphometric characteristics as well as on the genetic diversity of this important fish. The study hypothesized that declining of genetic diversity in different populations of $S$. sarwaridue to low level of migration flow, caused the isolation and inbreeding depression. Therefore, the present study was designed to estimate and compare the genetic varitaions between up and downstream population, and also assess the extent of migration flow between riverine population.

\section{Material And Methods}

Total 80 specimens of Sperata sarwari were collected during the year of 2016-2017 from up and downstream locations of four rivers of Punjab (Chenab, Jhelum, Ravi and Indus) with average body weight $305 \pm 0.5$ and length $37 \pm 0.5$ detail showed in Table 1 and fig 1. The Specimens were transferred to Molecular Research Lab of the Department of Zoology, Government college University Faisalabad, Pakistan in ice containing Polythene bag for molecular analysis.

\section{DNA Extraction}

Genomic DNA of 54 specimens was extracted by using Genomic DNA isolation kit (Favorgen FATGK-001). Fish samples were weighed up to $25 \mathrm{mg}$ and ground in liquid nitrogen, then transferred into new micro-centrifuge (Sigma, D37520) tube. Added $200 \mu \mathrm{L}$ FATG 1 buffer and mixed very well by micro pestle or pipette tip. Added $20 \mu \mathrm{L}$ Proteinase $\mathrm{K}(10 \mathrm{mg} / \mathrm{ml})$ to the sample mixture and mixed through vortex. Incubated the sample at $60^{\circ} \mathrm{C}$ until the tissue was lysed completely. Vortex (BV1000) for 10-15 minutes during incubation to break up the tissue sample. Briefly spin the tube to remove drops from the inside of the lid. Added $4 \mu \mathrm{L}$ of $100 \mathrm{mg} / \mathrm{ml}$ RNase and incubated for 2 mint at room temperature. Added $200 \mu \mathrm{L}$ FAGT 2 buffer to the sample mixture. Mixed thoroughly by pluse-vortexing (BV1000) and incubated at $70{ }^{\circ} \mathrm{C}$ for 10 minutes. Briefly spined the tube to remove drops from the lid. Added $200 \mu \mathrm{L}$ ethanol (96-100\%) to the sample and mixed thoroughly by pulse- voterxing (BV 1000). Briefly spined the tube to remove drops from the lid. Placed FATG mini column in collection tube and transfer the mixture to mini column tube. Centrifuged (Sigma, D37520) for 1 minute, then placed FATG mini column tube to new collection tube. Washed the mini column tube with $500 \mu \mathrm{L}$ with W1 buffer by Centrifuge (Sigma, D37520) for 1minute then discard the follow through. Washed mini column tube with $750 \mu \mathrm{L}$ wash buffer by centrifuged for 1 minute then discard the follow through. Centrifuged (Sigma, D37520) for an additional 3 mint to dry column. Placed the mini column tube in Elution tube and added 50-200 $\mu \mathrm{L}$ elution buffer or $\mathrm{ddH}_{2} \mathrm{O}$ to the center of membrane at mini column and stand FATG mini column tube 
for three minutes. Centrifuged (Sigma, D37520) for 2 minutes to elute DNA. Stored the DNA at $4{ }^{0} \mathrm{C}$ or $-20{ }^{0} \mathrm{C}$ for quantification and PCR amplification.

\section{Random Amplified Polymorphic DNA and PCR reaction}

To assess the genetic variations in S. sarwari population, the condition of polymerase chain reaction (PCR) was optimized by using the Random Amplified Polymorphic DNA (RAPD) markers. Ten RAPD markers were selected from the genomic Library on the basis of GC contents (\%) and band reproducibility for the amplification of genomic DNA in S. sarwari (NCBl;www.genelink.com; Table 1) and were named as SS Makers.

DNA, 2.5 mm mixed dNTPs, 2.5 uL 10X Taq DNA polymerase buffer, $2.5 \mathrm{uL} 25 \mathrm{~mm} \mathrm{MgCl}$, 0.5 ul each primer, 0.5 uL Taq DNA polymerase, that was gently mixed. PCR reaction was as follows: $95^{\circ} \mathrm{C}$ for $3 \mathrm{~min}, 95^{\circ} \mathrm{C}$ for $30 \mathrm{sec}, 45^{\circ} \mathrm{C}$ for $30 \mathrm{sec}, 72^{\circ} \mathrm{C}$ for $1 \mathrm{~min}, 35$ cycles, followed by a $10 \mathrm{~min}$ final extension at the $72{ }^{\circ} \mathrm{C}$. The detail of concentration of reagents that were applied for the optimization of genetic markers is given in Table 4. PCR profile for amplification of DNA sample was optimized by up and down range of annealing temperature. The PCR optimization conditions of denaturation occurred in two steps, primer annealing, primer extension, final extension and final amplified product of RAPD markers. The PCR optimized pattern is given in Table 3. 1.5\% agarose gel was used for resolution of resolution of different band patterns. Amplified fragments of each marker were observed under the UV transilluminator and the photograph was taken through the gel documentation system (Syngene, 2000) for further genetic analyses.

\section{Genetic Analysis}

RAPD markers amplified different patterns of genome in S. sarwari, examined under the UV transluminator and photographed using Gel documentation (Syngene, 2000). Molecular analysis program of gel documentation system was applied for scoring the amplified locus size of individual genome. These loci patterns of different individuals of $S$. sarwari population were analyzed by molecular software program POPGENE ver16/32and Gen AlEx 6.4 for estimation of genetic diversity in $S$. sarwari.

\section{Results}

\section{Genomic Amplification}

Total ten RAPD (SS) primer were used to analyze the genetic diversity of endangered species $S$. sarwari and 50 scroable band generated by these primers. The band size ranged from $250-1050 \mathrm{bp}$ and showed 37 polymorphic amplified band with $74.0 \%$ polymorphism among the eight different populations of $S$. sarwari.The amplification of RAPD primers of different size of loci in all populations of $S$. sarwari collected from various up and downstream of different river of Punjab indicated the variation in allelic frequencies (Table 3).

\section{Genomic diversity among population}

The values of genetic indices observed (na) effected (ne) alleles, Nei's diversity, Shannon Index and polymorphism of 80 individuals of eight up and downstream populations of $S$. sarwari collected from different rivers (i.e., River Chenab, Jhelum, Ravi and Indus) of the Punjab analyzed by the 10 RAPD (SS) Primers which showed the lowest polymorphism (2\%), na (1.02), ne (1.02), H (0.010,0.008) and I $(0.032,0.001)$ in up and down stream Ravi populations while the other up and down stream population of Chenab, Jhelum and Indus populations of $S$. sarwari (Table 4). The polymorphism of up and downstream populations of Chenab, Jhelum, Ravi and upstream population of Indus was less than $60 \%$ which showed that the level of intra population genetic variation was very low and level of inbreeding was high within populations. Every population of up and downstream formed its own isolated population, which decrease the genetic flow. The downstream population of Indus with highest polymorphism (62\%) indicated the high genetic variations (Table 4). 
The genetic diversity content such as heterozygosity (Ht), diversity (Hs), Genetic variation (Gst) and genetic flow (Nm) between the populations was used in the present study to detect population structure. The heterozygosity $(\mathrm{Ht}, 0.3574)$, intra population diversity ( $\mathrm{Hs}, 0.1743)$, inter population genetic variations (Gst, 0.5124) and genetic flow (Nm, 0.4758)in eight populations of $S$. sarwari. The genetic variability higher and low genetic flow observed between eight populations of $S$. sarwari(Table 5).

\section{Genetic Distance and Genetic Identity}

The genetic distance found between the up and the downstream population of $S$. sarwari ranged from 0.0013 to 0.5738 and genetic similarities between up and downstream populations of $S$. sarwari ranged from 0.5634 to 0.9987 . Both up and downstream Ravi populations were completely isolated due to large genetic distance (0.5738) and the lowest genetic similarities (0.5634) from the other six up and down stream populations of $S$. sarwari.

\section{Dendrogram}

Cluster analysis was done on the basis of RAPD genetic distances through POPGENE 32 among and between the various up and downstream populations of $S$. sarwari. The $1^{\text {st }}$ group consists of the upstream and the downstream population of the River Ravi $(5,6)$ which showed the complete isolation of these two populations due to large genetic distance from the other populations, $2^{\text {nd }}$ group composed of the upstream and the downstream population of the River Chenab $(1,2)$, whereas $3^{\text {rd }}$ group formed by the upstream and the downstream population of the River Jhelum and the River Indus. The $3^{\text {rd }}$ group was subdivided into 3 subgroups, the $1^{\text {st }}$ sub group was the combination of the up and downstream population of the River Jhelum and the River Indus $(3,8)$ and $2^{\text {nd }}$ and $3^{\text {rd }}$ subgroups were developed by the downstream of the River Jhelum (4) and upstream of the River Indus (7) (Fig. 1).

\section{Discussion}

Genome amplification is necessary for the genetic analysis, such as genetic diversity, heterozygosity, gene flow between populations and genetic diversity among and between the populations. Ten RAPD primers were used to amplify eight populations of $S$. sarwari collected from the various up and downstream areas of the four rivers (i.e., River Chenab, Jhelum, Ravi and Indus). Ten RAPD primers generated 50 scorble bands with an average range from $250-1050 \mathrm{bp}$. The spacious range of the band size was comparable with previous studies, where 5 RAPD markers produced 45 amplicon, (250-2000 bp) in Eutropiichthys vachapopulation (Chandra et al. 2010). The six RAPD primer produced 48 and 44 scorable bands in tilapia (Mahboob et al. 2019; Khafaji et al. 2019), 16 RAPD markers generate 197 bands ranged from 114-2000 bp in six golden mahseer populations (Shafi et al. 2016) and 12 RAPD primers produced 87 bands, amplified band ranged from 400-1250 bp in four Rohu populations (Kabir et al. 2017). Moreover the present studies was corelated with the previous studies Vasave et al. 2014 (rainbow trout and snow trout), Hasan and Goswami 2015 (cat fish (Mystus vittatus)), and six RAPD prime produced 89 and 60 amplified bands with 50-1500 bp in genetic analysis of Capoeta copeta gracilis and piracanjuba fish population (; Lopera-Barrero et al. 2019) respectively. The result revealed that the genetic measures (polymorphism, observed alleles, effected alleles, gene diversity and Shannon index) of downstream Indus population (na 1.60, ne 1.44, h 0.250 , I 0,367) was high as compared to other up and downstream population of $S$. sarwari. The lowest value of na (1.02), ne (1.02), h (0.010, $0.008)$ and I $(0.032,0.001)$ was observed in both up and downstream Ravi populations of $S$. sarwari. These results are in line with the isolated up and downstream populations of Capoeta copeta gracilis,in which the genetic measure reliably higher in downstream population of Capoeta copeta gracilis (Hossein et al. 2013). The result showed that the average polymorphism (47\%) of eight populations of $S$. sarwari was less than $60 \%$. The pervious results of polymorphism were also related to the present study. The average $46.81 \%$ polymorphism was observed in walking catfish (C. batrachus) (Miah et al. 2020). The average 48.38\% polymorphism was observed in four populations of Rohu collected from different geographical areas (Kabir et al. 2017), polymorphism in Rohu population of 47.89\% (Fayyaz et al. 2014), 45\% (Barman et al. 2003), and 46.5\% (Islam \& Alam, 2004). The polymorphism ranged from $2-62 \%$ in all populations of $S$. sarwari collected from the up and downstream of selected rivers, i.e., River Chenab, Jhelum, Ravi and Indus. The average polymorphism of eight populations of S. sarwari 
was less than $60 \%$, which indicated the low genetic variability among eight populations and the present study is similar to the previous study of Kabir et al. (2017) in four populations of Rohu sampled from different geographical regions.

The total mean values of na, ne, $\mathrm{h}$ and I was $1.42,1.31,0.174$ and 0.255 which was moer or less similar to pervious study of Shafi et al. (2016) in six population of golden mahseer inhabited in different geographical region. The total mean value of Nei's gene diversity and Shannon Index in present research work was less than 0.5 which indicated that there was less genetic variability and inbreeding coefficient was high (Shafi et al. 2016). The present study was in agreement with the previous study on golden mahseer, where the average values of Nei's gene diversity and Shannon Index was very low (Shafi et al. 2016). The heterozygosity ( $\mathrm{Ht}$ ), diversity (Hs), genetic variation (Gst) and genetic flow (Nm) ranged from 0.101-0.478, 0.052-0.273, $0.282-0.743$ and $0.178-1.670$, respectively for eight populations of $S$. sarwari (Table 4). The total heterozygosity (Ht 0.3574$)$,

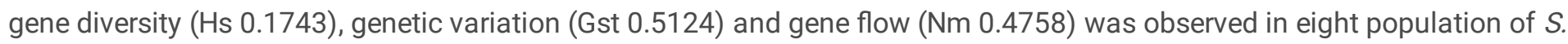
sarwari. Vasave et al. (2014) found relatively similar results in rainbow trout and snow trout. He observed high value of genetic variation (Gst 0.6835) with low gene flow (0.2316) among populations of rainbow trout and snow trout. The present study was in line with the previous studies for genetic variation that was found in tilapia species (Gst $=0.583)($ Heba et al.2013), Capoeta capoeta gracilis (Hossein et al. 2013), Elops machnata (Ramandaevi and Thangaraj 2014) and in walking catfish (C. bartrachus) (Gst = 0.19823) (Miah et al. 2020). Due to natural barriers the freshwater fish showed low migration rate and higher genetic variation (Rodriguez et al. 2007; Kusmini et al. 2011).

The genetic distance and similarity was observed among and between the eight populations ranged from 0.0496 to 0.5378 and 0.5634 to 0.9987 , respectively (Table 5). The above findings are comparable with the previous studies on other fish species. Hossein et al. (2013) also reported that the genetic distance between two up and downstream populations of Capoeta capoeta gracilisranged from 0.1455 to 0.7382 and observed that the two populations were isolated from each other. In the present study, eight populations of $S$. sarwari collected from the up and downstream of the different rivers of the Punjab also showed the segregation among and between the populations. The isolation of populations was reflected by the genetic distances and complicated mechanism of genetic flow (Rana et al. 2004). Low migration of fish significantly affected the fish population of the up and downstream region and causes the reduction in genetic exchange among two populations (McAllister et al., 2001). Furthermore, the dams and barrages extend to striking changes in aquatic environment which directly affect fish populations (Craig 2000). The genetic variations found in present study were also studied and observed in the up and downstream populations of C. c. gracilis, which were also the cause of barriers established by dams and barrages in rivers. These barriers were geographically segregated from each other because there was no chance for gene flow among and between populations of C. c. gracilis (Hossein et al. 2013). Barriers effect on the gene flow and caused the isolation of up and downstream population with high genetic variation and fragmentation interacted with genetic diversity of freshwater fish populations (Van Leeuwen et al. 2017). Our study investigated the lowest level of genetic flow (0.178-1.670) between the up and downstream of dams and barrages populations of $S$. sawari, ultimately causing the increase of genetic variation (population divergence) towards the highest level of inbreeding depression. However, the populations of $S$. sarwari above and below dams/barrages showed a significant higher level of genetic difference, which is the indication of isolation in populations. This study also reported that the higher inbreeding coefficient caused the declining of $S$. sarwari.

\section{Conclusion}

In this study it was concluded that the genetic analysis of Sperata sarwari sampled from different up and downstream populations of four rivers (i-e Chenab, Jhelum, Ravi and Indus) is main source to observed genetic difference between the populations. The physical barriers cause the isolation of S.sawari and it also showed that Ravi population was completely isolated due to presence of high genetic variability and low gene flow between populations. The highest genetic distance and lowest genetic similarity was assess between both up and downstream Ravi population and other up and downstream riverine populations.

\section{Declarations}




\section{Acknowledgments}

The authors are grateful to the Department of Zoology, Government College University, Faisalabad-Pakistan, and Department of Fisheries, Punjab, Pakistan to providing us research facility to carry out this research.

\section{Authors contribution}

Concept and design of study was carried out by Dr. Farhat Jabeen and Dr. Inayat Ullah Malik, data acquisition and data analysis by Dr. Asma Aziz, Dr. Farhat Jabeen, and Dr. Inayat Ullah Malik. Fish Sampling was done with the help of Zahid Sahrif Mirza, Muhammad Ahmad Raza, Sami Ullah Bhati and Noor Afshan. The final draft was prepared Dr. Asma Aziz and reviewed by Dr Farhat Jabeen, Mr. Muhammad Nafees and Adiba Khan Sehrish.

\section{Declaration}

We declare that this manuscript is an original research, has been written by us and has not been submitted in any other journal for publication. The experimental work is almost entirely our own work; the collaborative contributions have been clearly indicated. It has been declared that all authors are agreed to submit in this journal.

\section{References}

Achrem M, Skuza L, Kirczuk, L, Domaga, AJ, Pilecka-Rapacz M, Czerniawski R (2015) Genetic variation of Salmo trutta L. populations from the catchment areas of the Rega, Parseta and Wieprza rivers evaluated by RAPD \&SSR markers. Folia Biol (Krakow) 63:1-7

Ahmad JN, Azizah MN, Adikwu IA, Istifanus WA, Abalis,GE, Muchlisin, ZA (2012) Diversity and distribution of fishes of Gaji River, Bauchi state Nigeria. Adv Environ sci- Int J bioflux Soci 4 (2): 50 -54

Amit J, Preeti J 2020 Molecular Characterization of Uttarakhand Tari Region Carp species by using RAPD Markers. Int J Res Eng Sci and Manag 3(3):2581-5792

Asabrga MC, Adebayo AS, Ugwumba OA, Ugwumba AAA, Anumudu Cl (2014) Genetic Characterization of fin fish species from the Warri River at Ubeji, Niger Delta, Nigeria. Afr J Biotechnol 13(27):2689-2695.

Barman HK, Barat A, Yadav BM, Banerjee S, Meher PK, Jana RK, Reddy PVG (2003) Genetic variation between four species of Indian major carps as revealed by random amplified Polymorphic DNA assay. Aquaculture 217: 115-123

Carlson SM, Cunningham CJ, Westley PAH (2015) Evolutionary rescue in a changing world. Trends Ecol Evol 29: 521-530.

Casper HA, Van L. Kristine D, Jon M, Claudia JL, Asbjorn V 2(017) Habitat fragmentation has interactive effects on the population genetic diversity and individual behavior of a freshwater salmonid fish. DOI: 10.1002/rra.3226

wileyonlinelibrary.com/journal/rra

Cheng F, Li W, Wu Q, Hallerman E, Xie S (2013) Microsatellite DNA variation among samples of bronze gudgeon, Coreius heterodon, in the mainstem of the Yangtze River, China. Ichthyol Res 60(2):165-171

Cheng F, Zhao S, Schmidt BV, Ye L, Hallerman EM, Xie S (2018) Morphological but no genetic differentiation among fragmented popu- lations of Hemiculter leucisculus (Actinopterygii, Cyprinidae) from a lake complex in the middle Yangtze, China. Hydrobiologia 809(1): 185-200

Coleman RA, Gauffre B, Pavlova A, Beheregaray LB, Kearns J, Lyon J, Sasaki M, Leblois R, Sgro C, Sunnucks P (2017) Artificial barriers prevent genetic recovery of small isolated populations of a low-mobility freshwater fish. Heredity https://doi.org/10.1038/s41437-017-0008-3

Page $7 / 21$ 
Cooke SJ, Lapointe N W R, Martins EG, Thiem JD, Raby GD (2013) Failure to engage the public in issues related to inland fishes and fisheries: strategies for building public and political will to promote meaningful conservation. J Fish Biol 83:9971018

Craig J F (2000) Large dams and freshwater fish biodiversity. Prepared for thematic review II.1: Dams, ecosystem functions and environmental restoration. World Commission on Dams (WCD) Cape Town

DeHaan PW, Bernall SR, DosSantos JM, Lockard LL, Ardren WR (2011) Use of genetic markers to aid in re-establishing migratory connectivity in a fragmented metapopulation of bull trout (Salvelinus confluentus). Can J Fish Aquat Sci 68: 19521969.

Duran CN, Appleby T, Clark D, Wood M, Batley IJ, Edwards D (2009) AutoSNPdb: an annotated single nucleotide polymorphism database for crop plants. Nucleic Acids Res 37: 951-953.

Filho VAM, Freitas MV, Ariede R B, Lira LVG, Mendes NJ, Hashimoto DT (2018) Genetic Applications in the Conservation of Neo-tropical Freshwater Fish. Biological Resources of Water. http://dx.doi.org/10.5772/intechopen.73207

Ferguson A, Reed TE, Cross TF, McGinnity P, Prodöhl P A 2019 Anadromy, potamodromy and residency in brown trout Salmo trutta: the role of genes and the environment. J Fish Biol 95:692-718

.Gallardo B, Clavero M, Sanchez M I, Vila M (2016). Global ecological impacts of invasive species in aquatic ecosystems. Glob Change Biol 22: 151-163

Gupta SS, Homechudhuri S (2015) Taxonomic and functional diversity of fish assemblage in three interconnected tropical Rivers in India in accordance with limiting similarity hypothesis. J Glob Biosci 4: 2842-2858

Gold AC, Thompson SP, Piehler MF, (2017) Water quality before and after watershed-scale implementation of stormwater wet ponds in the coastal plain. Ecol Eng 105: 240-251

Hansen MM. (2003) Application of molecular markers in population and conservation genetics, with special emphasis on fishes. DSc Thesis, Faculty of Natural Sciences, University of Aarhus 68 (Unpublished data).

Heba AM, Abd El-Kader Z G, Abdel-Hamid K, Mahrou F (2013) Genetic diversity among three species of Tilapia in Egypt detected by random amplified polymorphic DNA Marker. J Appl Biol Sci 7(2): 57-64.

Hedrick P W (2005) Genetics of Population, 3rd Ed. Jones and Bartlett Pub. Co: Sudbury, MA, USA.

Homola JJ, Scribner K. T, Elliott R F, Donofrio M C, Kanefsky J, Smith K M, McNair J N (2012) Genetically derived estimates of contemporary natural straying rates \& historical gene flow among Lake Michigan lake sturgeon populations. Transa Am Fish Soc 141(5):1374-1388.

Hossein AF, Farahmand H, Silva DM, Bastos RP, Khyabani A, Hassan A F (2013) Fourteen years after the Shahid-Rajaei dam construction: an evaluation of morphometric and genetic differentiation between isolated up and downstream populations of Capoeta capoeta gracilis (Pisces: Cyprinidae) in the Tajan River of Iran. Genet Mol Res 12(3):3465-3478

Islam MS, Alam MS (2004) Randomly amplified polymorphic DNA analysis of four different populations of the Indian major carp, Labeo rohita (Hamilton). J Appl Ichthyol 20(5): 407-412

Jeong JH, Byeung CL, Ki OY, Su KJ (2012) Influence of small-scale habitat patchiness on the genetic diversity of the Korean endemic species Saussureachabyoungsanica (Asteraceae). Biochem Syst Ecol43:14-24

Kabir MA, Rahman MS, Begum M, Faruque M F (2017) Genetic diversity by RAPD in four populations of rohu Labeo rohita. Croat J Fish 75: 1-9

Page $8 / 21$ 
Kahl U, Stephan HI, Robert JR, Jurgen B (2008) The impact of water level fluctuations on the year class strength of Roach: Implications for fish stock management. Limnologica 38:258-268.

Al-Khafaji TY, Ziyadi MSF, Musad MK (2019) DNA Fingerprints of Two Tilapia Fish Species of Euphrates River at Governorate of Al-Muthanna Using RAPD Markers. Eng Technol J 37 (3):345-349

Kelly P P, Khela S, Ferri C, Field D (2013) Climate-change impact considerations for freshwater-fish conservation, with special reference to the aquarium and zoo community. Int Zoo Yearbook 47: 81-92

Kusmini I, Rudy I, Mulyasari G (2011) Genetic characterization of the kelabau (Osteochilus kelabau) from several locations in West Kalimantan using RAPD method. Bio News 10(4): 449-454.

Lal K K, Mandal A, Singh RK, Punia P, Kapoor D, Chauhan UK, Singh SP, Mohindra V (2006). Genetic divergence in two featherback fishes, Chitala chitala and Notopterus notopterus. J Appl Ichthyol 22:369-373.

Lopera-Barrero NM, Santos SCA, Castro PL, Souza FP, Poveda-Parra AR, Pandolfi VCF, Yamachita AL, Urrea-Rojas AM, RojasMeza DA, Ribeiro RP (2019) Genetic diversity of Piracanjuba populations in fish stocking programs in the Tietê River, Brazil. Rev Colomb Cienc Pecu 32(2)

Liu L, Zhang X, Li C, Zhang H, Yanagimoto T, Song N, Gao T (2019) Population genetic structure of Marbled Rockfish, Sebastiscus marmoratus (Cuvier, 1829), in the northwestern Pacific Ocean. ZooKeys 830: 127. 10.3897/zookeys.830.30586

Luikart G, Ryman N, Tallmon DA, Schwartz MK, Allendorf F W (2010) Estimation of census and effective population sizes: the increasing usefulness of DNA-based approaches. Conserv Genet 11(2):355-373

Mahboob S, Al-Ghanim KA, Al-Misned F, Alkahem Al-Balawi HF, Norah MA, Al-Mulhim. (2019) Genetic diversity in tilapia populations in freshwater resvior by randomly amplified polymorphic DNA markers. Saudi J Biol Sci 26: 363-367

Marimuthu K, Wei KSC, Xavier R, Mohammad Aminur Rahman A M, Arshad A, Aliyu-Paiko M, Subramaniam Sreeramanan S, Raj GM (2016) Genetic variations and phylogenetic relationship among snakehead fish, Channa Striatus (Actinopterygii: Perciformes: Channidae) population based on RAPD-PCR analysis. J Env Biotech Res 2(1): 1-6

Maskur 2002 Conservation program of fish germplasm in inland waters. Indonesia Journal of Aquacult 1(3):139-144

Martinez A, Willoughby R J, Chirstie RM (2018) Genetic diversity in fish influenced by habitat type and life history variation. Ecol Evo 1-10. DOI:10.1002/ece3.4661

McAllister DE, Craig JF, Davidson N, Delany S (2001) Biodiversity impacts of large dams. Background Paper Nr. 1. Prepared for IUCN / UNEP / WCD

Medeiros JD, Cantao ME, Cesar DE, Nicolas M.F, Diniz CG, Silva VL, Vasconcelos ATR., Coelho C.M (2016) Comparative metagenome of a stream impacted by the urbanization phenomenon. Braz J Microbiol 47:835-845

Miah Md F, Rahman T, Shipa AS Chakarbarty A (2020) RAPD- based genotyping of walking catfish (Clarias batrachus) in population of Bangladesh. J Ent Zoo St 8(1):885-888

Mojekwu TO, Oguntade OR, Oketoki T O, Usman A B (2012) Genetic variability of Tilapia in different water bodies using RAPD markers. Proceedings of the 25th Annual Conference of the Biotechnology Society of Nigeria. Held at National Open University, Abuja. 26th - 31st August, 2012.

Morita K, Yamamoto S (2002) Effects of habitat fragmentation by damming on the persistence of stream-dwelling charr populations. Conserv Bio 16: 1318-1323

Page $9 / 21$ 
Muneer P M A, Gopalakrishnan A, Remya S, Basheer VS, Ponniah AG (2011) Genetic variation and phylogenetic relationship between two species of yellow catfish, Horabagrus brachysoma and H. nigricollaris (Teleostei: Horabagridae) based on microsatellite and RAPD markers. Mol Bio Rep 38(4): 2225-2232.

Pujolar JM, Deleo GA, Ciccotti E, Zane L (2009) Genetic composition of Atlantic and Mediterranean recruits of European eel Anguilla anguilla based on EST-linked microsatellite loci. J Fish Bio 74:2034-2046

Pauly D, Zeller D (2016). Catch reconstructions reveal that global marine fisheries catches are higher than reported and declining. Nat Commun 7: 10244. https://doi.org/10.1038/ ncomms10244.

Ramanadevi V, Thangaraj M (2014) Genetic Diversity analysis of Elops machnata (Forskal) populations in South East and West Coasts of India Using RAPD Markers. Not Sci Biol 6(4): 399-406.

Rana RS, Bhat V K, Lakhanpal S, Lakra S W (2004) Comparative genetic diversity in natural an hatchery populations of Indian Major Carps (C. catla \& L. rohita). Aus J Anim Sci 17(9): 1197-1203.

Reis RE (2013) Conserving the freshwater fishes of South America. Int Zoo Yearbook 47:65-70.

\section{https://doi.org/10.1111/izy.12000}

Roberts JH, Angermeier PL, Hallerman EM (2013) Distance, dams and drift: what structures populations of an endangered, ben- thic stream fish? Freshw Biol 58(10): 2050-2064.

Rodriguez CG, Morris MR, Dubois NS, de-Queiroz K (2007) Genetic variation and phylogeography of the swordtail fish Xiphophorus cortezi (Cyprinodontiformes, Poeciliidae). Mol Phylogenet Evo 143: 111-123.

Ruzafa AP, Wangüemert MG, Lenfant P, Marcos C, Charton JAG (2006) Effects of fishing protection on the genetic structure of fish populations. Biol Conserv 129:244-255.

Santos RMB, Fernandes LS, Cortes RMV, Varandas SGP, Jesus JJB, Pacheco FAL (2017) Integrative assessment of river damming impacts on aquatic fauna in a Portuguese reservoir. Sci. Total Environ. 601-602: 1108-1118.

Shafi N, Ayub J, Ashraf N, Mian A, Malik IU (2016) Genetic diversity in different populations of mahseer (Tor putitora) in Pakistan: A RAPD based study. Int J Agri Bio 18:1181-1187.

Sivaraman GK, Barat A, Ali S, Pandey NN, Joshi KD, Mahanta PC (2010) An analysis of genetic diversity among the Indian cold water fishes (Pisces: Cyprinidae) using RAPD markers. IUP J Genet Evol 3(2): 31-40.

Smith C T, Reid SB, Godfrey L, Ardren WR (2011) Gene flow among Modoc sucker and Sacremen to sucker populations in the upper Pit River, California \& Oregon. J Fish Wild Manag 2(1): 72-84

Syandri H, Azrita, Aryani N (2013) Size distribution, reproduction and spawning habitat of the bilih (Mystacoleucus padangensis ) in Singkarak Lake. Bawal 5(1):1-8

Terborgh J, Lopez L, Nuñez P, Rao M, Shahabuddin G, Orihuela G, Balbas L (2001) Ecological meltdown in predator-free forest fragments. Sci 294: 1923-1926.

Usman B A, Agbebi OT, Bankole MO, Oguntade OR, Popoola M O (2013) Molecular characterization of two cichlids populations (Tilapia guineensis and Sarotherodon melanotheron) from different water bodies in Lagos State, Nigeria. Acad J 4(5): 71-77.

Vasave S, Saxena A, Srivastava S K, Barat A (2014) Genetic diversity between Rainbow Trout (Oncorhynchus mykiss, Walbaum) and Snow Trout (Schizothorax richardsonii, Gray) by Rapd Markers. Biol Chem Res 40-51. 
Vollestad L A, Serbezov D, Bass A, Bernatchez L, Olsen E M, Taugbol A (2012) Small-scale dispersal and population structure in stream-living brown trout (Salmo trutta) inferred by mark-recapture, pedigree reconstruction, and population genetics. Cana J Fish Aqua Sci 69(9):1513-1524

Waples RS, Do C (2010) Linkage disequilibrium estimates of contemporary using highly variable genetic markers: a largely untapped resource for applied conservation and evolution. Evol Appl 3(3): 244-262

Williamson-Natesan EG (2005) Comparison of methods for detecting bottlenecks from microsatellite loci. Conserv Genet 6(4): 551-562

Wu J, Huang J, Han X, Xie Z, Gao X (2003). Three-Gorges Dam: Experiment in habitat fragmentation? Sci 300: 1239-1240.

Xia JH, Bai Z, Meng Z, Zhang Y, Wang L, Liu F, Jing W, Wan ZY, Li J, Lin H, Yue, GH (2015) Signatures of selection in tilapia revealed by whole genome re-sequencing. Sci Rep 5:4168.

Xia JH, Wan ZY, Ng ZI, Wang L, Fu GH, Lin G, Feng L,Gen HY (2014) Genome-wide discovery and in silico mapping of gene associated SNP in Nile tilapia. Aquac 432:67-73. 61

\section{Tables}

Table 1. Different populations of $S$. sarwari collected from the upstream and downstream of four rivers (River Chenab, Ravi, Jhelum and Indus).

\begin{tabular}{llll}
\hline Sr. No & Location & Sites & Sample size \\
\hline 1 & River Chenab & Tarimue Head Upstream &
\end{tabular}

1 River Chenab Tarimue Head Upstream

10

\begin{tabular}{lll} 
& Downstream & 10 \\
\hline 2 & River Ravi & $\begin{array}{l}\text { Head Balloki } \\
\text { Upstream }\end{array}$ \\
& Downstream & 10 \\
\hline
\end{tabular}

3 River Jhelum Head Rasool Upstream

10

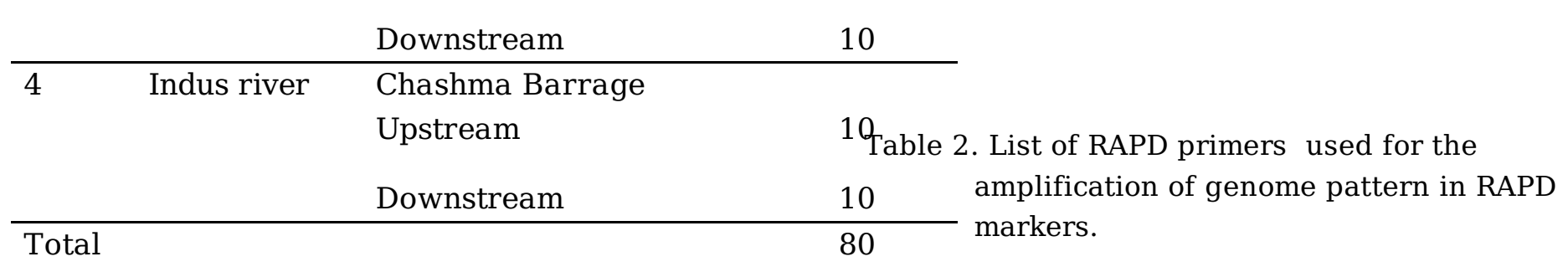




\begin{tabular}{|c|c|c|}
\hline Sr. No & Primer Sequence & $\%$ of GC contents \\
\hline 1 & $5^{\backslash}$ CTGCTGGGAC $3^{\backslash}$ & $70 \%$ \\
\hline 2 & $5^{\backslash}$ CATCССССТG $3^{\backslash}$ & $70 \%$ \\
\hline 3 & $5^{\prime}$ TGGACCGGTG3\} $&{70 \%} \\
{\hline 4} &{5^{\prime} \quad \text { TCTGGTCAGG } 3^{\prime}} &{60 \%} \\
{\hline 5} &{5^{\prime} \quad \text { GTCGCCGTCA } 3^{\prime}} &{70 \%} \\
{\hline 6} &{5^{\prime} \quad \text { GGGTAACGCC } 3^{\prime}} &{70 \%} \\
{\hline 7} &{5 \backslash \text { AGCCAGCGAA3 }} &{60 \%} \\
{\hline 8} &{5^{\prime} \quad \text { TGCCGAGCTG } 3^{\prime}} &{70 \%} \\
{\hline 9} &{5^{\prime} \quad \text { GGTGACGCAG } 3^{\prime}} &{70 \%} \\
{\hline 10} &{5^{\prime} \text { GGTCCCTGAC } 3^{\prime}} &{70 \%} \\
$\hline
\end{tabular}

Table 3. Description of amplicons in genomic DNA with polymorphism, gene pool frequency and range size of 10 primers on different population of $S$. sarwari collected from different rivers of the Punjab, Pakistan.

\begin{tabular}{|c|c|c|c|c|c|}
\hline RAPD Markers & No. of Amplicon & $\begin{array}{c}\text { No. of } \\
\text { Polymorphic } \\
\text { bands }\end{array}$ & Polymorphism (\%) & $\begin{array}{c}\text { Gene pool } \\
(\%)\end{array}$ & Loci Range bp \\
\hline SS1 & 5 & 4 & 80 & 10 & $300-850$ \\
\hline SS2 & 4 & 4 & 100 & 8 & $300-850$ \\
\hline SS3 & 5 & 3 & 60 & 10 & $300-850$ \\
\hline SS4 & 4 & 3 & 75 & 8 & $300-850$ \\
\hline SS5 & 3 & 2 & 67 & 6 & $300-650$ \\
\hline SS6 & 7 & 5 & 71 & 14 & $250-1050$ \\
\hline SS7 & 6 & 4 & 67 & 12 & $300-1050$ \\
\hline SS8 & 5 & 4 & 80 & 10 & $300-800$ \\
\hline SS9 & 7 & 5 & 71 & 14 & $250-1050$ \\
\hline SS10 & 4 & 3 & 75 & 8 & $300-1050$ \\
\hline Total & 50 & 37 & 74 & 100 & $250-1050$ \\
\hline
\end{tabular}

Table 4. Description of genetic indices; observed alleles (na), effected alleles (ne), Nei's diversity (h) and Shannon Index (I) of the upstream (US) and the downstream (DS) population of $S$. sarwari from four different rivers of the Punjab, Pakistan. 


\begin{tabular}{lccccc}
\hline $\begin{array}{l}\text { Riverine } \\
\text { ?opulation }\end{array}$ & Polymorphism & na & ne & h & I \\
\hline JS Chenab & 58 & 1.56 & 1.44 & 0.240 & 0.346 \\
JS Chenab & 56 & 1.56 & 1.44 & 0.240 & 0.346 \\
JS Jhelum & 54 & 1.54 & 1.37 & 0.214 & 0.315 \\
JS Jhelum & 52 & 1.52 & 1.42 & 0.231 & 0.331 \\
JS Ravi & 2 & 1.02 & 1.02 & 0.010 & 0.032 \\
JS Ravi & 2 & 1.02 & 1.02 & 0.008 & 0.001 \\
JS Indus & 56 & 1.56 & 1.33 & 0.202 & 0.303 \\
JS Indus & 62 & 1.60 & 1.44 & 0.250 & 0.367 \\
\hline Mean & & 1.42 & 1.31 & 0.174 & 0.255 \\
\hline
\end{tabular}

Table 5. Estimation of Genetic variations (Hetrozygosity among population= Ht; Diversity within population= Hs, Genetic variations among populations $=$ Gst and Genetic flow $=\mathrm{Nm}$ ) among and between the eight populations of S. Sarwari collected from different upstream and downstream of the four rivers of the Punjab, Pakistan.

\begin{tabular}{ccccc}
\hline RAPD Primer & $\mathrm{Ht}$ & $\mathrm{Hs}$ & $\mathrm{Gst}$ & $\mathrm{Nm}^{*}$ \\
\hline SS1 & 0.226 & 0.097 & 0.485 & 0.960 \\
SS2 & 0.101 & 0.052 & 0.432 & 0.822 \\
\hline SS3 & 0.401 & 0.177 & 0.542 & 0.706 \\
\hline SS4 & 0.469 & 0.127 & 0.7364 & 0.247 \\
\hline SS5 & 0.422 & 0.088 & 0.743 & 0.178 \\
SS6 & 0.478 & 0.269 & 0.434 & 0.771 \\
\hline SS7 & 0.241 & 0.114 & 0.467 & 0.968 \\
\hline SS8 & 0.275 & 0.193 & 0.282 & 1.670 \\
SS9 & 0.467 & 0.273 & 0.427 & 0.904 \\
\hline SS10 & 0.439 & 0.236 & 0.488 & 1.069 \\
\hline Mean & 0.3574 & 0.1743 & 0.5124 & 0.4758 \\
\hline
\end{tabular}

Table 6. Genetic distance (d) and genetic similarity (S) among eight populations of $S$. sarwari collected from the upstream (US) and the downstream (DS) of the River Chenab (C), Jhelum (J), Ravi (R) and Indus (I) based on the construction of Phylogenetic relationships by using POPGENE 32. 


\begin{tabular}{|c|c|c|c|c|c|c|c|c|c|c|}
\hline & $\begin{array}{l}\text { Population } \\
\text { ID }\end{array}$ & 1 (USC) & $\begin{array}{c}2 \\
\text { (DSC) }\end{array}$ & $\begin{array}{c}3 \\
\text { (USJ) }\end{array}$ & 4 (DSJ) & $\begin{array}{c}5 \\
\text { (USR) }\end{array}$ & $\begin{array}{c}6 \\
\text { (DSR) }\end{array}$ & $\begin{array}{c}7 \\
\text { (USI) }\end{array}$ & 8 (DSI) & \\
\hline \multirow{8}{*}{$\begin{array}{r}\text { Genetic } \\
\text { Distance } \\
(\mathrm{d})= \\
0.0013- \\
0.5738\end{array}$} & 1 (USC) & $* * * *$ & 0.9516 & 0.8211 & 0.7744 & 0.6202 & 0.6137 & 0.7949 & 0.8432 & \multirow{8}{*}{$\begin{array}{l}\text { Genetic } \\
\text { Similarity } \\
(\mathrm{S})=0.5634- \\
0.9987\end{array}$} \\
\hline & 2 (DSC) & 0.0496 & $* * * *$ & 0.794 & 0.7849 & 0.6202 & 0.6137 & 0.8463 & 0.8348 & \\
\hline & 3 (USJ) & 0.1971 & 0.2307 & $* * * *$ & 0.9575 & 0.5698 & 0.5634 & 0.9274 & 0.9670 & \\
\hline & 4 (DSJ) & 0.2556 & 0.2422 & 0.0434 & $* * * *$ & 0.5769 & 0.5705 & 0.9343 & 0.9303 & \\
\hline & 5 (USR) & 0.4777 & 0.4777 & 0.5625 & 0.5501 & $* * * *$ & 0.9987 & 0.5736 & 0.5963 & \\
\hline & 6 (DSR) & 0.4883 & 0.4883 & 0.5738 & 0.5613 & 0.0013 & $* * * *$ & 0.5673 & 0.5898 & \\
\hline & 7 (USI) & 0.2295 & 0.1669 & 0.0754 & 0.068 & 0.5557 & 0.5669 & $* * * *$ & 0.9302 & \\
\hline & 8 (DSI) & 0.1705 & 0.1806 & 0.0335 & 0.0722 & 0.5169 & 0.528 & 0.0724 & $* * * *$ & \\
\hline
\end{tabular}

\section{Figures}

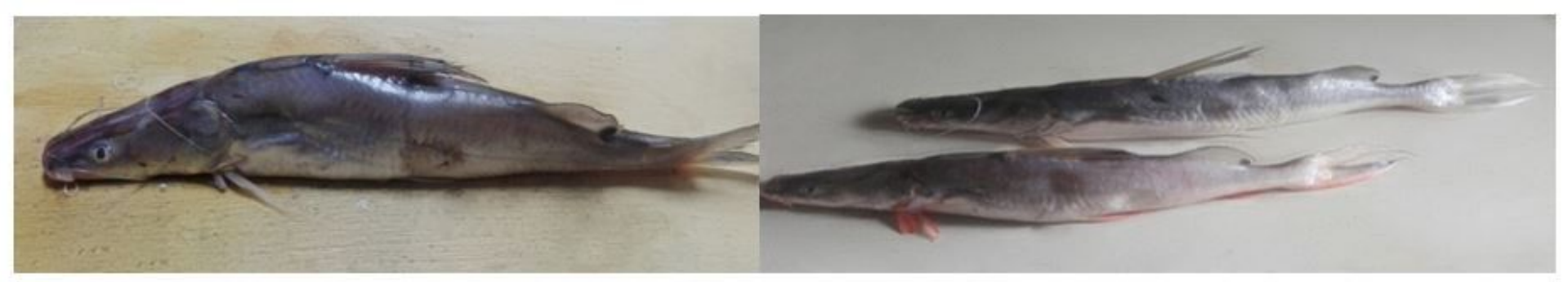

Figure 1

Specimen of Sperata sarwari collected from different up and downstream regions of four Rivers (Chenab, Jhelum, Ravi and Indus) of Punjab. 


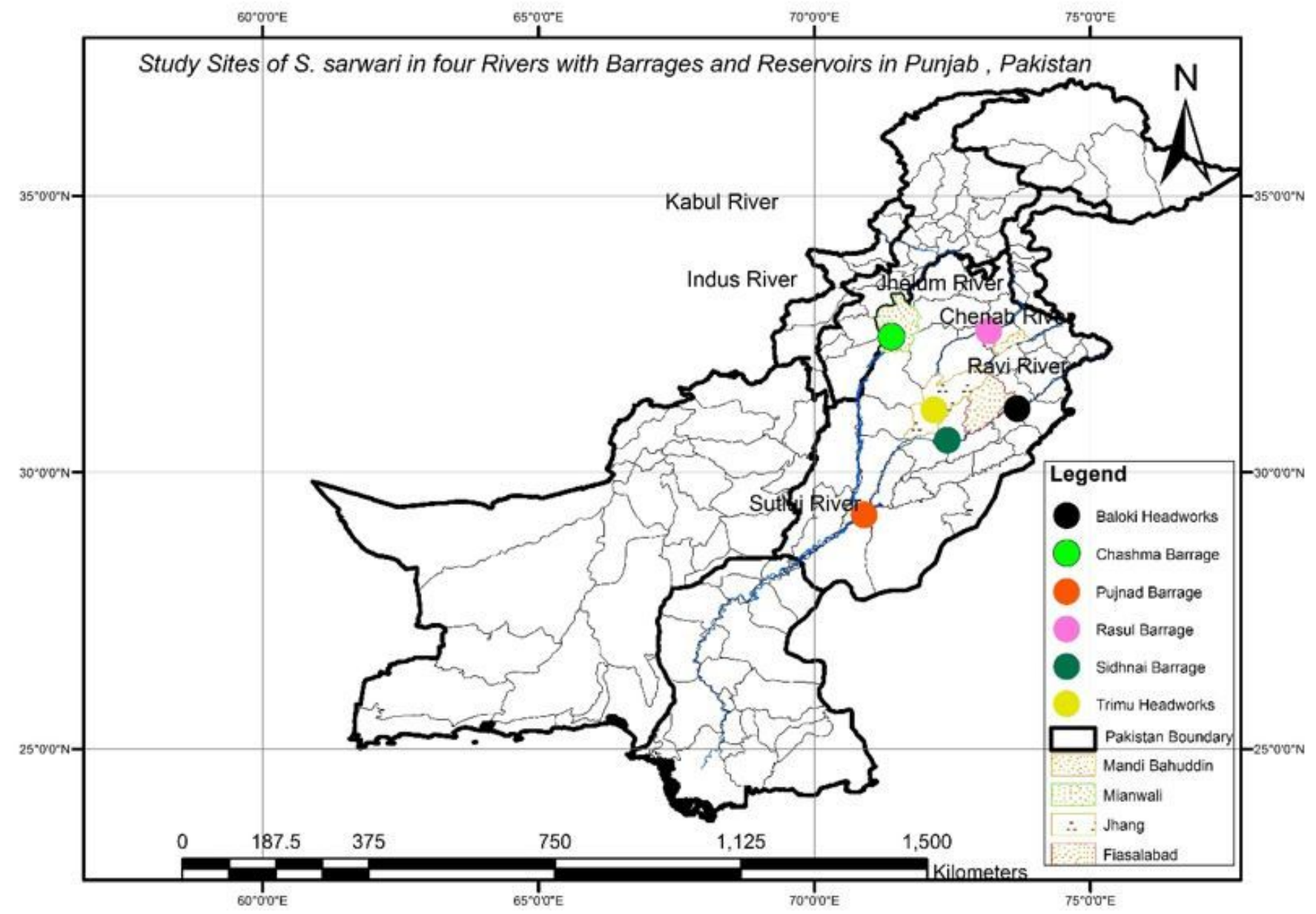

Figure 2

The map of Sample collection. Note: The designations employed and the presentation of the material on this map do not imply the expression of any opinion whatsoever on the part of Research Square concerning the legal status of any country, territory, city or area or of its authorities, or concerning the delimitation of its frontiers or boundaries. This map has been provided by the authors. 


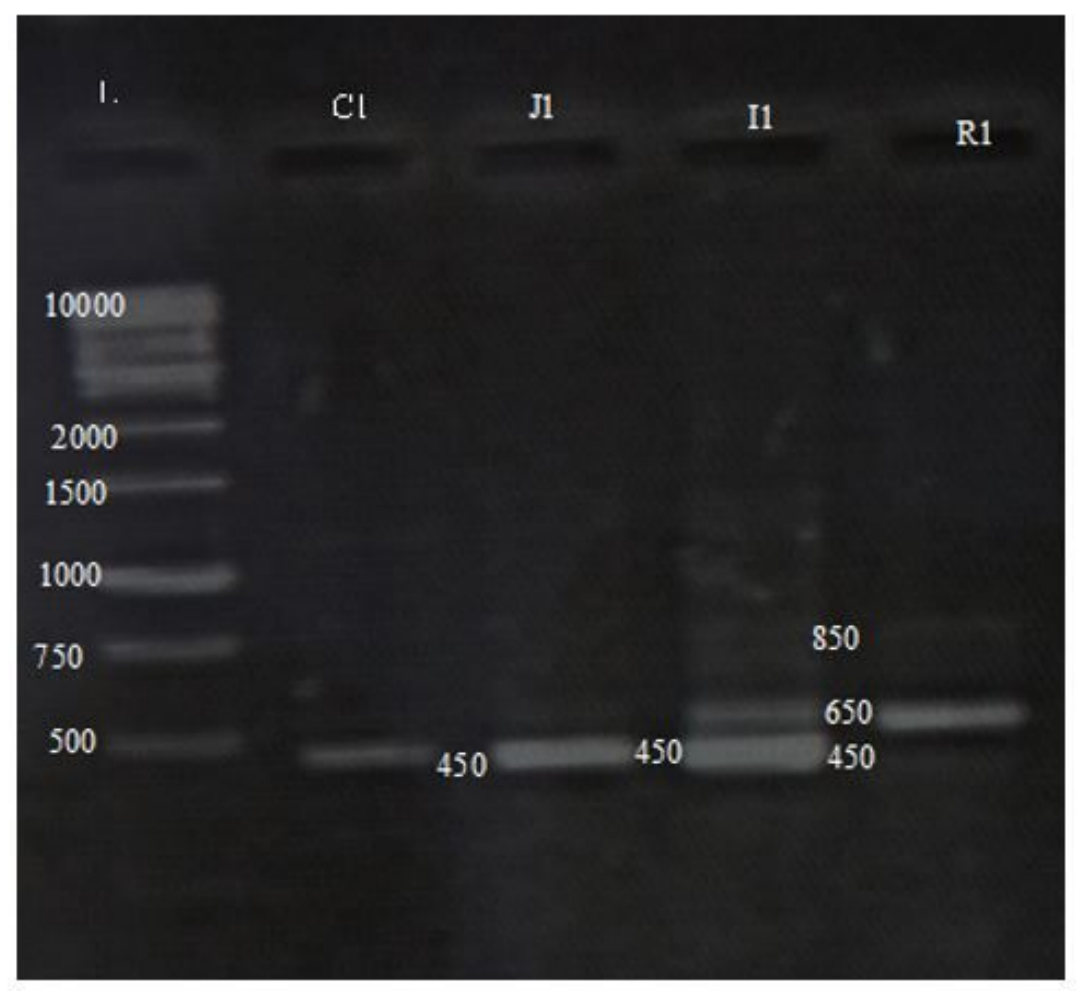

\section{Figure 3}

The amplification of 1SS (RAPD) Primer in four different riverine population, 1 Ladder; 2 River Chenab specimen; 3 River Jhelum; 4 River Indus and 5 River Ravi

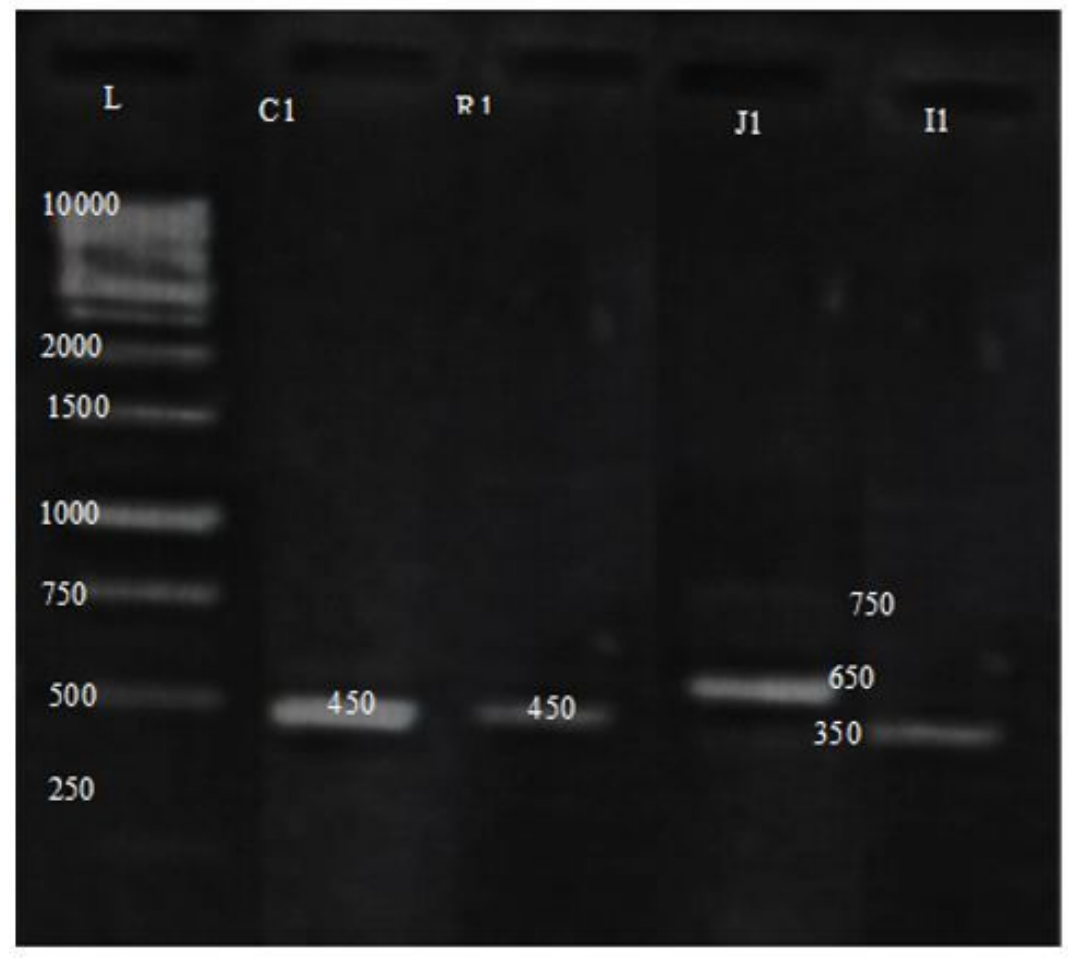

\section{Figure 4}

The amplification of 2SS (RAPD) primer in four different riverine population 1 marker; 2 River Chenab specimen; 3 River Ravi; 4 River Jhelum and 5 River Indus. 


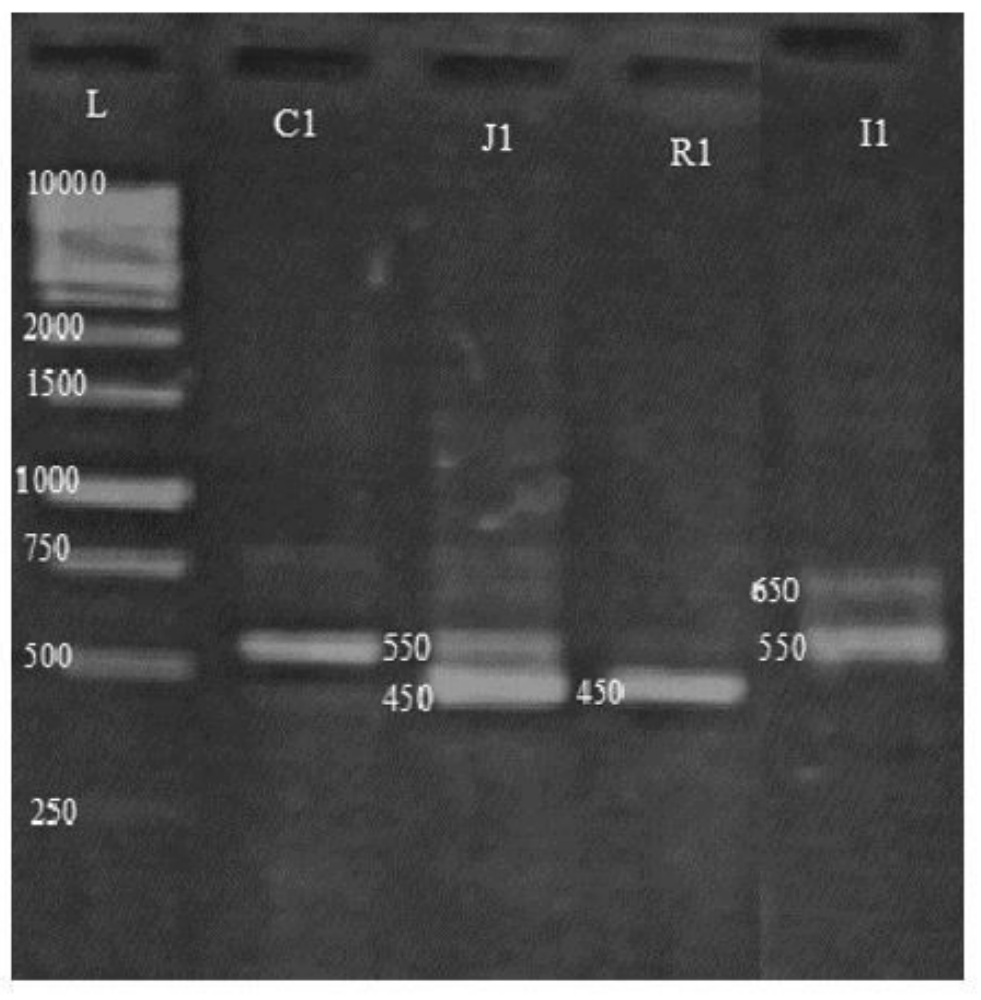

\section{Figure 5}

The amplification of 3SS (RAPD) primer in four different riverine populations 1 Ladder; 2 River Chenab specimen; 3 River Jhelum; 4 River Ravi and 5 River Indus.

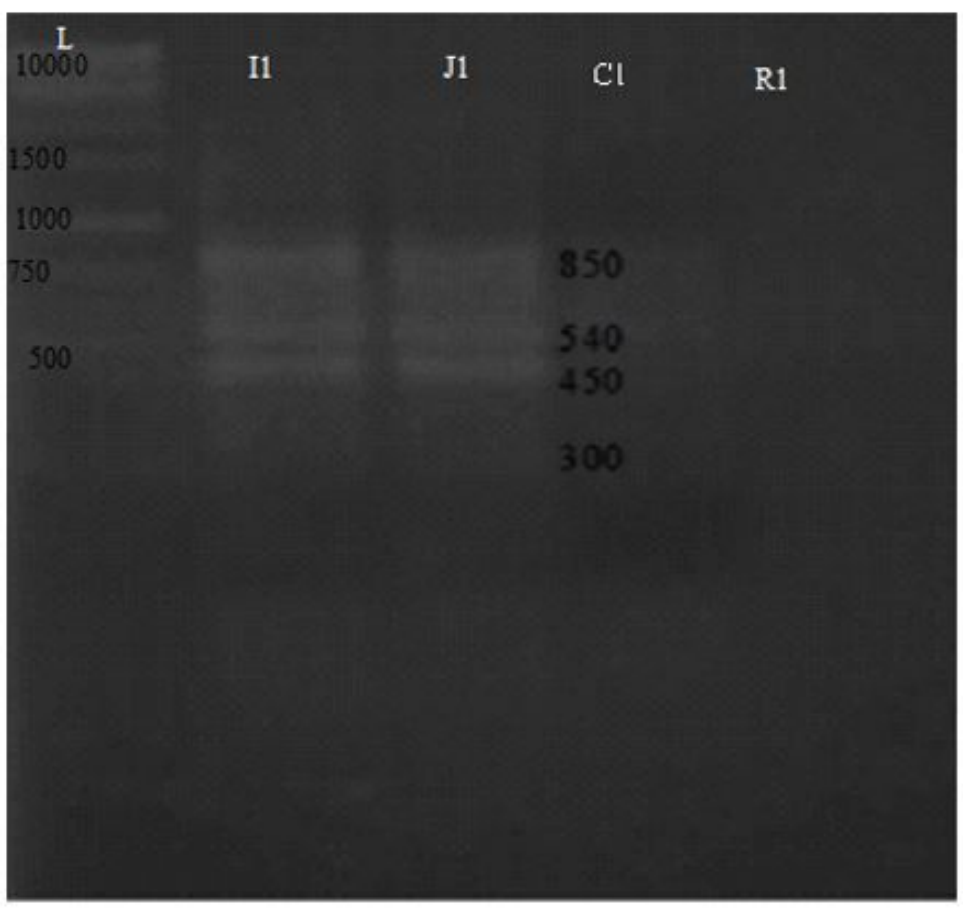

\section{Figure 6}

The amplification of 4SS (RAPD) primer in four different riverine population 1 Ladder; 2 River Chenab specimen; 3 River Ravi; 4 River Jhelum and 5 River Indus. 


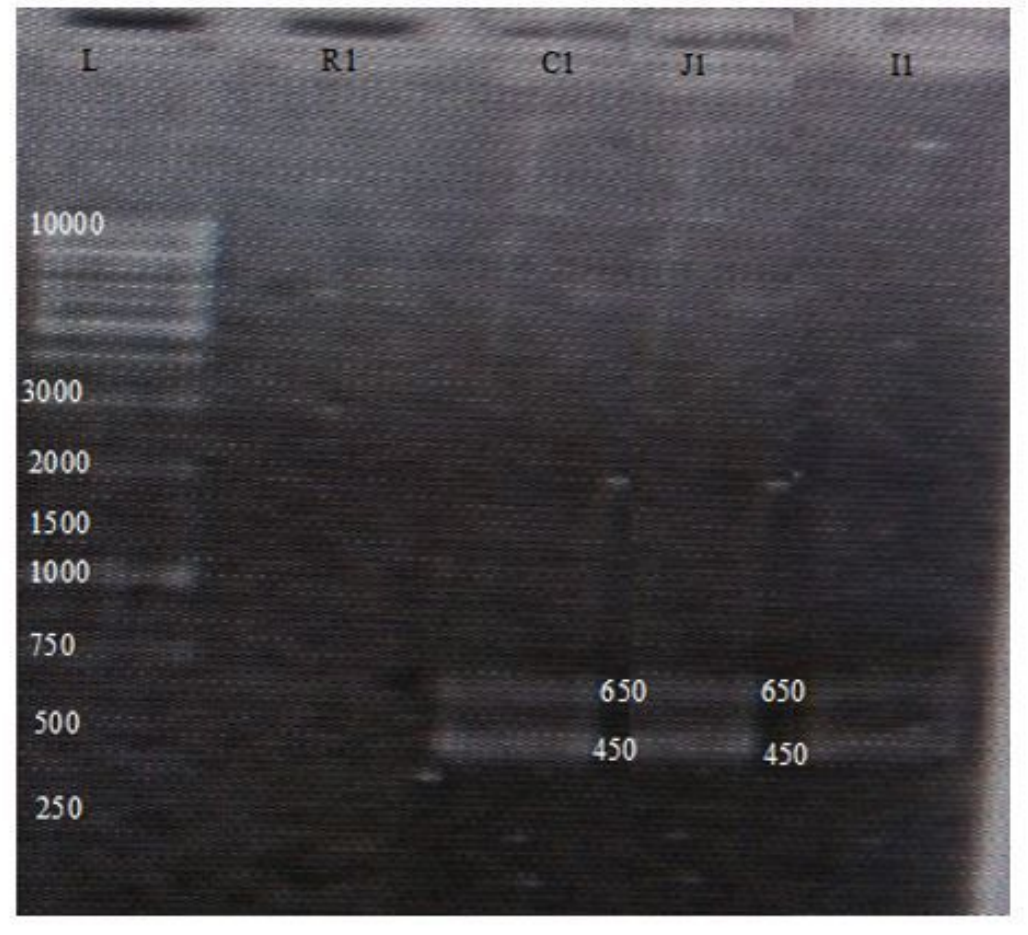

\section{Figure 7}

The amplification of 5 SS (RAPD) primer in four different riverine populations 1 marker; 2 River Ravi specimen; 3 River Chenab; 4 River Jhelum and 5 River Indus.

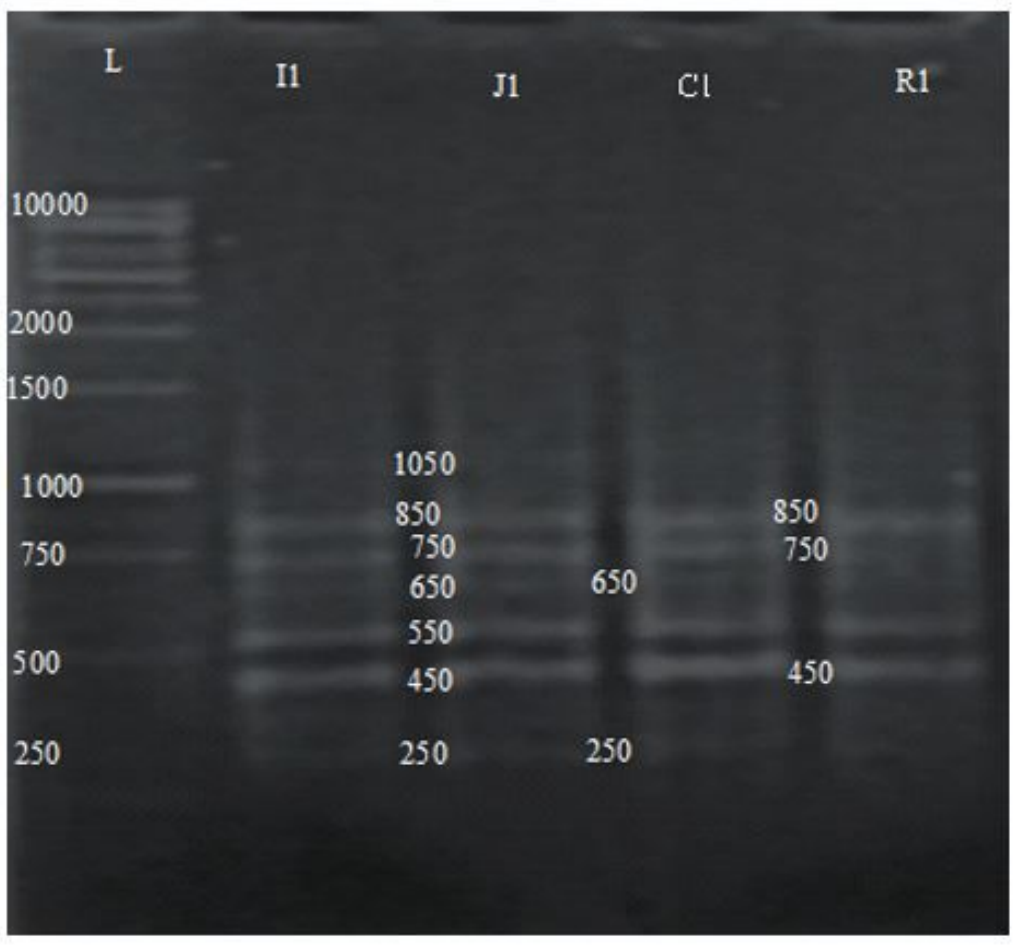

\section{Figure 8}

The amplification of 6SS (RAPD) primer in 4 different riverine population 1 Ladder; 2 River Ravi specimen; 3 River Jhelum; 4 River Indus and 5 River Ravi. 


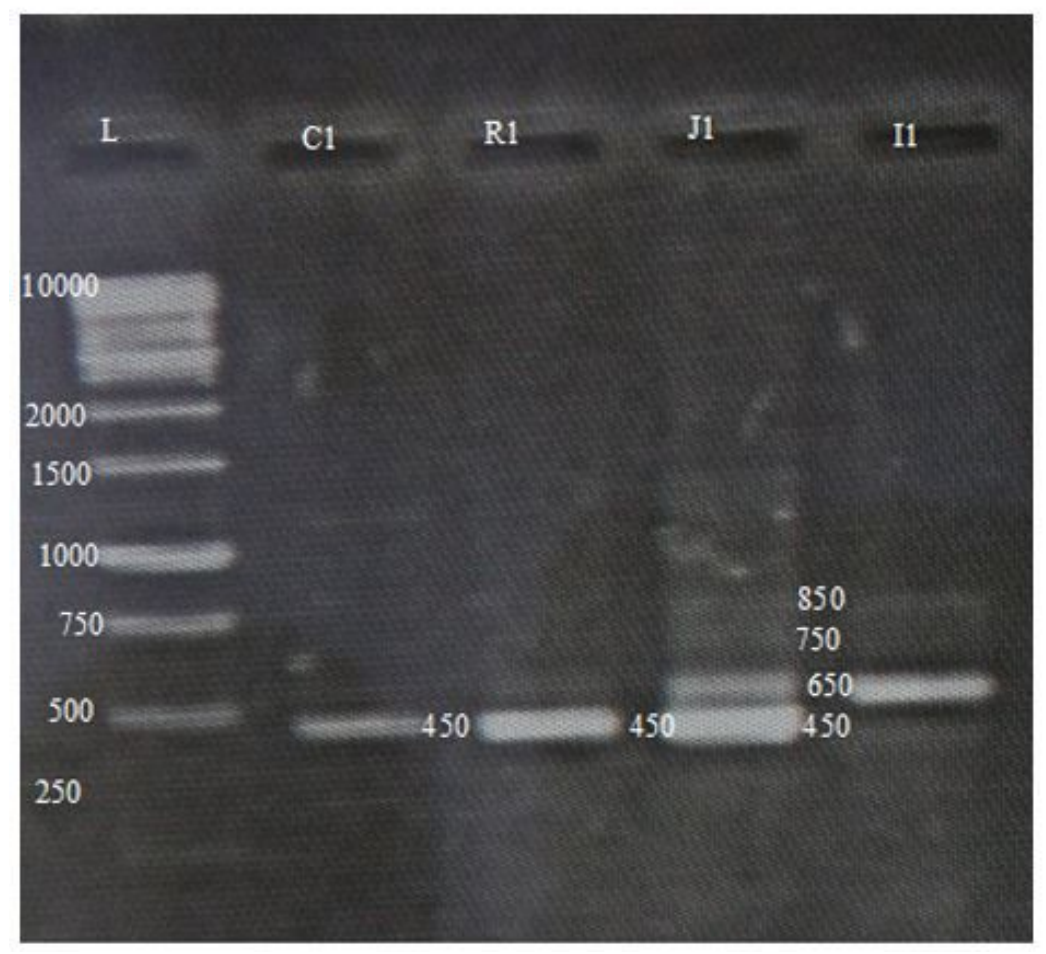

\section{Figure 9}

The amplification of 7 SS RAPD primer in 4 different riverine population 1 marker; 2 River Chenab specimen; 3 River Ravi; 4 River Jhelum and 5 River Indus.

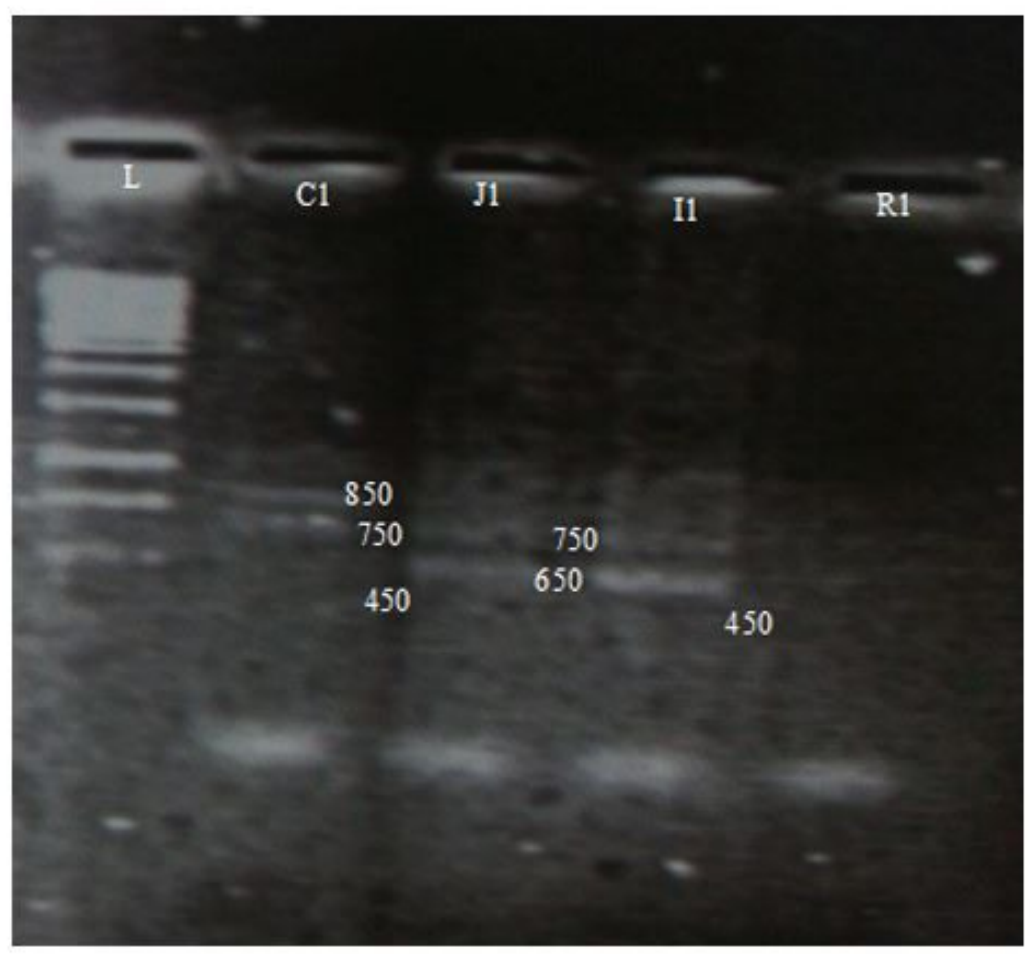

\section{Figure 10}

The amplification of 8SS RAPD Primer in 4 different riverine population 1 marker; 2 River Chenab specimen; 3 River Jhelum; 4 River Indus and 5 River Ravi. 


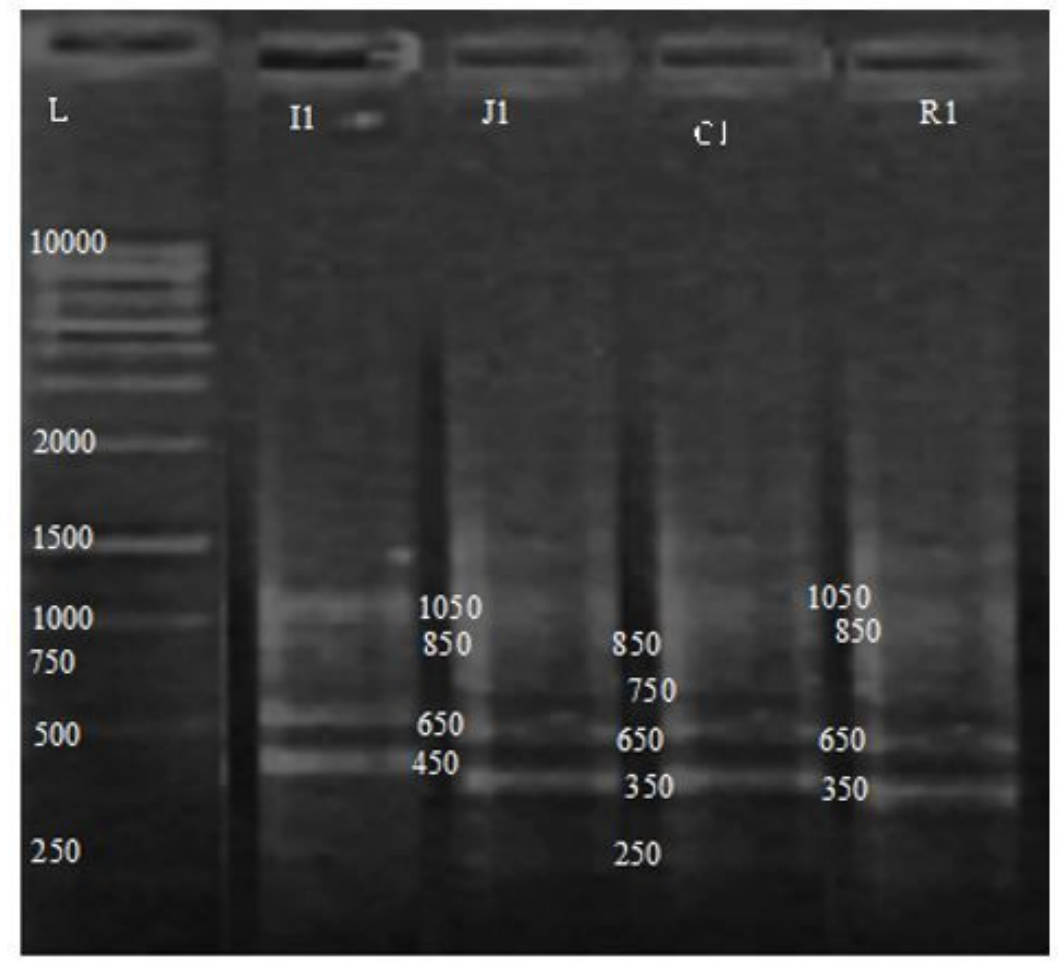

\section{Figure 11}

The amplification of 9SS RAPD Primer in 4 different riverine population 1 Ladder; 2 River Chenab specimen; 3 Jhelum; 4 River Ravi and 5 River Indus

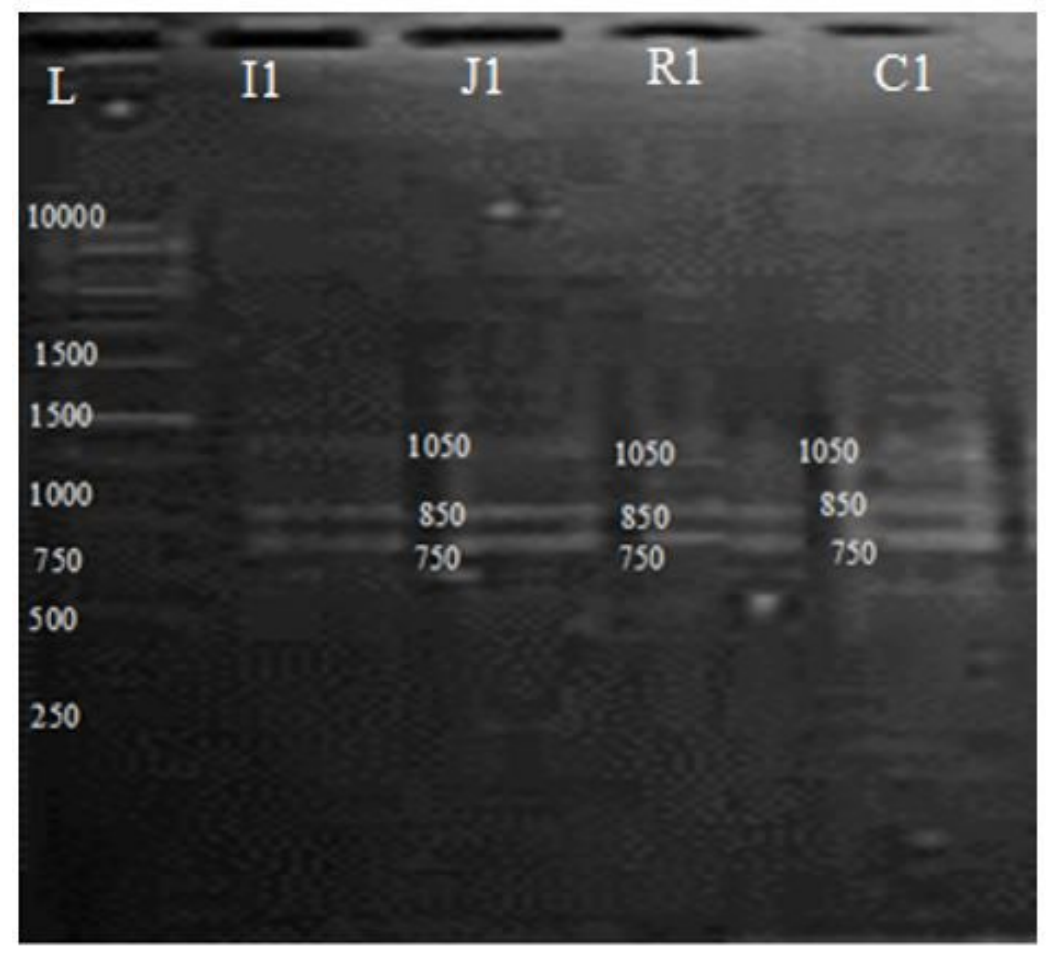

\section{Figure 12}

The amplification of 10SS (RAPD) primer in 4 different riverine population 1 Ladder; 2 River Indus specimen; 3 Jhelum; 4 River Ravi and 5 River Chenab. 


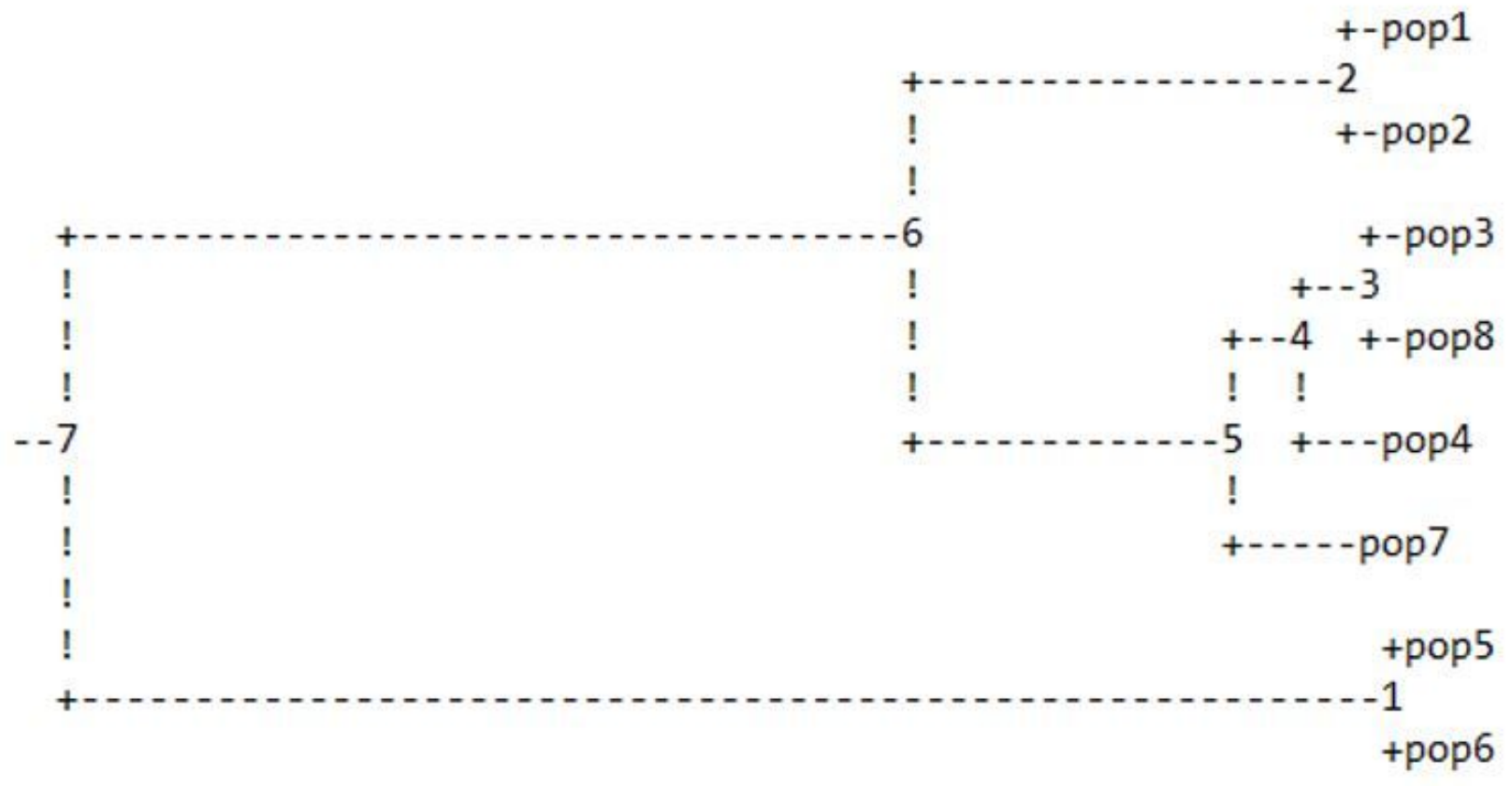

Figure 13

UPMGA dendrogram based on genetic distances by RAPD markers among eight different populations of $\mathrm{S}$. sarwari of the four rivers (Chenab=1, 2, Jhelum=3, 4, Ravi=5, 6 and Indus=7, 8) of the Punjab, Pakistan. 